\title{
O POETA E O OUTRO: A ALTERIDADE COMO TOMADA DE CONSCIÊNCIA EM MÁRIO E DRUMMOND
}

\author{
Thaís Cristina da Silva-UnB ${ }^{1}$
}

\begin{abstract}
RESUMO: O trabalho realiza uma comparação sobre a temática da alteridade na poética de Mário de Andrade e Carlos Drummond de Andrade. Partimos do pressuposto de que a construção desse outro está diretamente relacionada à posição e ao engajamento dos respectivos poetas dentro das distintas fases do modernismo brasileiro. A análise dos poemas Dois poemas acreanos e Operáro no mar corrobora essa conjetura, em Mário, o otimismo da primeira geração promove a idealização do outro e a comoção pela identidade comum, já Drummond, oriundo da geração de 30 e da consciência do atraso, ressalta a impossibilidade do encontro com o outro. A alteridade surge na poética de Mário como instância cultural, e em Drummond, como forma de conhecimento, de convocação à luta de classes.
\end{abstract}

PALAVRAS-CHAVE: Alteridade; engajamento; modernismo brasileiro; Mário de Andrade; Drummond.

ABSTRACT: The article makes a comparison on the theme of otherness in the poetics of Mário de Andrade and Carlos Drummond de Andrade. We assume that the construction of another is directly related to the position and the engagement of their poets in the different phases of brazilian modernism. The analysis of poems - Dois poemas acreanos and Operário no mar proves this theory. In Mario, the optimism of the First Generation promotes idealization of the other and the commotion by common identity, as Drummond, from the Generation of 30 and acute underdevelopment awareness, underscores the impossibility of meeting the other. Otherness emerges in the poetics of Mario as a cultural body, and Drummond, as a form of knowledge, to call class struggle.

KEYWORDS: Alterity; engagement; brazilian modernism; Mário de Andrade; Drummond.

\section{INTRODUÇÃO}

No seu livro A conquista da América: A questão do outro, Todorov proclama em sua síntese que o outro deve ser descoberto. Tal descoberta encarada com espanto perante sua obviedade, já que o homem, em suas palavras, nunca está só, constrói-se em sua dimensão social. Nesta obra publicada em 1982, Todorov tem como objetivo apontar a questão da alteridade, numa época em que o debate sobre esse tema era de extrema importância dentro da conjetura política e socioeconômica em que se deparava o mundo: países latino-americanos

\footnotetext{
${ }^{1}$ Mestra em Literatura e Práticas Sociais pela Universidade de Brasília- UnB. Membra do Grupo de Pesquisa Literatura, Femininismos e Revolução do Departamento de Teoria Literária e Literaturas da Universidade de Brasília. E-mail: thaisdasilva.unb@gmail.com
} 
emergindo de ditaduras militares, nações africanas em pleno processo de descolonização, guerras civis; um retrato do abismo que separava o primeiro e o terceiro mundo (LAROCCA, FERNANDES, 2013). Nesse cenário de incertezas e desequilíbrios, o autor se propõe a examinar o conceito de alteridade recontando a história da descoberta da América, em uma narrativa com tons mais literários do que propriamente histórico.

Se o pensar sobre o outro esbarra em muitas problemáticas e debates sendo alvo de investigações em diferentes áreas do conhecimento como a antropologia, a psicologia e a sociologia, o retorno promovido pelo autor no exame do conceito de alteridade segue um caminho de estabilidade ao traçar o seu correlato: a identidade. Em certo ponto de A conquista da América, o autor afirma "Somos todos descendentes diretos de Colombo, é nele que começa nossa genealogia - se é que a palavra começo tem um sentido. A partir desta data [1492], o mundo está fechado" (TODOROV, 1999, p. 5). É fato plausível que a identidade ocidental configurou-se com essa "conquista da América". Mais do que isso, até hoje esse encontro emite seus reflexos na sociedade.

Fica muito fácil compreender o porquê de Todorov voltar séculos do momento que o separa de sua escrita para pensar sobre alteridade; se a chegada às Américas pelos europeus anuncia a presente identidade, segundo ele, então é nesse exato momento que se funde a figura do outro, do desconhecido. Cabe ressaltar, de ambas as partes, que interagem nesse movimento. Pensar numa alteridade condiciona, invariavelmente, a construção de uma identidade que se configura como média por seu caráter homogêneo.

Gusmão (1999) descreve que somos herdeiros de uma falácia, a do homem branco, rico, civilizado, e acrescentamos eurocêntrico, como medida de todas as coisas. Se dessa junção de características os homens descobriram a totalidade de quem fazem parte, dando margem à construção dessa identidade ocidental homogênea, essa totalidade veio mediada por uma série de cortes e rupturas dos que se desviam de tal padrão. A diferenciação, portanto, "é responsável por (re)construir/(re)produzir a alteridade, por definir quem é o outro, e torná-lo identificável, (in)visível, previsível. Ao dividir, separar, classificar, normalizar, a diferenciação resulta na hierarquização.” (PACHECO, 2007, p. 3)

Ao todo o princípio da alteridade pode ser acompanhado de um binarismo secular promovido por este encontro: barbárie versus civilização, colonizador versus colonizado, centro versus margem. Se o modo de vida europeu espalhou e espelhou-se em todo o mundo, e para Todorov isso se deve à capacidade do europeu de compreender o outro para fins e objetivos que 
fortalecesse a si próprio, isso mostra que a identidade passa por uma perspectiva de poder, de quem têm meios de viabilizar sua voz. Fixar uma determinada identidade como a norma é uma das formas privilegiadas de hierarquização das identidades e das diferenças. O que toca num ponto problemático sobre essa questão: concomitantemente a irrupção da novidade, do transpor barreiras que o olhar sobre o outro promove, o processo de alteridade revela em si um traço de assimetria.

Temos historicamente um ser que ocupa posição central de medida das coisas que, no exercício "benevolente" de querer estar com o outro, compreendê-lo, ainda assim toma a voz para se descrever em relação ao outro; o que deveria ser um processo de nivelamento pode reforçar a desigualdade. Para Silva (2000), normalizar uma identidade significa atribuir a ela todas as características positivas possíveis em relação às quais as outras identidades só podem ser avaliadas de forma negativa. A trajetória da alteridade afirma-se, portanto, na tentativa de superação do eurocentrismo durante a modernidade e da egolatria que o caracteriza (SIDEKUN, 2006).

A alteridade vem sendo tratada há muito tempo por uma diversidade de espaços intelectuais, desde as ciências humanas e sociais passando pela psicologia. Tamanha fortuna crítica sobre o assunto e profícua diversidade de perspectivas dá margem à liquidez que toca a questão, sendo tal assunto ainda um construto apesar dos anos. Etimologicamente, segundo dicionário Houaiss, o termo vem do latim altaritas, de meados do século IV e do francês alterité (1270) e significa alteração, mudança. No século XX, passa a representar a "natureza ou condição do que é o outro, distinto" (apud MACHADO, 2012, p. 2).

$\mathrm{Na}$ sociologia, entende-se o conceito a partir de sua oposição, identidade, esta mediada pelas relações estabelecidas entre os indivíduos, sendo assim, a identidade refere-se às relações entre membros de uma mesma cultura, e a alteridade, a relação entre membros de culturas diferentes. Machado (2006) vincula ainda o conceito de alteridade intrínseco à teoria marxista a partir d'O Capital, por considerar o homem um ser social que desenvolve relações entre si, e pela constatação da existência do contato deste ser social com o outro a partir das relações que se estabelecem sob a óptica econômica. Mas é na antropologia que a temática tem mais força. Para essa ciência "a alteridade se constitui, desde sua emergência, em desafio a ser explicado" (ZANELLA, 2006, p.100), posto que a antropologia se estrutura com a temática da cultura. Segundo a antropologia, a alteridade representa a percepção e aceitação dos valores do outro, a qualidade do que é ser o outro. O desafio da alteridade na concepção antropológica abarca desde 
a comparação com a cultura europeia, que marca o início do reconhecimento do outro, e expande-se aos dias atuais:

[...] se no passado o outro era de fato diferente, distante e compunha uma realidade diversa daquela de meu mundo, hoje, o longe é perto e o outro é também um mesmo, uma imagem do eu invertida no espelho, capaz de confundir certezas pois, não se trata mais de outros povos, outras línguas, outros costumes. O outro hoje é próximo e familiar, mas não necessariamente é nosso conhecido. (GUSMÃO apud ZANOLLA, 2006, p. 2)

Podemos enxergar até mesmo uma interdependência entre cultura e alteridade nos preceitos da antropologia cultural. É efeito da alteridade a promoção da resistência contra a sistematização, pois suas barreiras sempre apontam para uma exterioridade. Para Sidekun, a alteridade trata-se da "irrupção histórica da novidade dentro dos processos culturais" (2006, p. 53). A dimensão da alteridade impulsiona a cultura para o apelo à novidade, para a busca de uma representação que transcenda as exclusões, com a qual possa se identificar como sujeito.

Transferimos, assim, a temática do "outro" para o âmbito cultural, precisamente a área da literatura, mais especificamente, o movimento modernista brasileiro, cuja contraface, a identidade, nacional, ganha importância fundamental no cenário literário. O caráter identitário da literatura brasileira sempre foi motivo de preocupação por boa parte da nossa crítica e dos autores. Candido (2000) aponta, no seu clássico estudo Formação da Literatura Brasileira, que a gênese da literatura brasileira respalda num caráter nacionalista, uma necessidade de tornar-se nação. A própria escola romântica no Brasil é vinculada à primeira tentativa, de fato, de estabelecermos um projeto de literatura independente, encontrando no romantismo, que se opõe ao classicismo e seus ditames estéticos coloniais, a base para o retrato de uma civilização que reivindica sua voz, que pinta um passado e proclama o presente.

O eu romântico tão característico da escola do romantismo, no Brasil, cede espaço a um apelo para o social. Sai à exacerbação individualista e entra a descrição das raças, dos costumes, da natureza e principalmente a tematização do outro, em específico, do índio promovido a ideário da identidade nacional. A intenção é das melhores, a execução expõe significativos equívocos: se os sentimentos dominantes que toca o romantismo brasileiro são o nacionalismo, o indianismo e o cristianismo, pois estes foram os ideais de nossa civilização (CANDIDO, 2000), os próprios, por sua vez, são registros do processo de colonização que se refletem na forma poética. 
A identidade no Brasil, assim como em outros pontos de colonização, tem a Europa como sinônimo de civilização, consistência e coerência (SPERBER, 1994). O indígena alçado ao posto de herói nacional é o construto de um ideário colonizado, traz no aspecto físico os traços da América e carrega consigo os valores de um cavalheiro medieval. Torna-se um ser lapidado para servir a uma identidade nacional. Nesse período, é complicado pensar em alteridade, quando o outro se apresenta tão diluído e homogeneizado, ao ponto de nem enxergarmos como contraparte ou excluído, sendo muito mais tematizado do que necessariamente representado.

Ao passo que, na escola modernista no Brasil, a alteridade emerge com mais evidência pelo posicionamento os quais os autores passam a tratar a dialética do geral e do particular, assumindo a própria originalidade do movimento. Os modernistas, em um primeiro momento, informam-se da arte europeia de vanguarda, porém conferem "um tipo local e universal de expressão, reencontrando a influência européia por um mergulho no detalhe brasileiro". (CANDIDO, 2000, p. 124). Resolvido esse conflito, o constrangimento que se travestia em idealização da mestiçagem brasileira é substituído pela valorização do negro, do mestiço, do indígena. Como menciona o crítico Antonio Candido, o que antes era deficiência transforma-se em superioridade no modernismo. Abre-se espaço para a celebração e para a pesquisa da pluralidade cultural, as rachaduras sociais, étnicas e históricas que compõem o registro brasileiro são matérias trazidas à consciência literária e, principalmente, o apelo a uma coletividade.

Como a crítica literária já aponta não se ignora o fato de que a primeira fase do modernismo carrega contradições na sua realização que vão aquém de seu propósito, duramente atacadas pela segunda fase do movimento. Mas a renovação que propunham é um passo importante para se pensar concretamente sobre alteridade na literatura brasileira. Nunca o desejo de estar com o outro, de compreendê-lo e concomitantemente a angústia do atestado dessa incapacidade esteve tão acentuada quanto nesse período. Nunca o outro se mostrou tão absoluto, tão concreto e tão diverso quanto se mostra aqui, assim como nunca a identidade brasileira foi encarada como construto de muitas variáveis sociais e históricas, de marcante e vívida heterogeneidade. Ao lado da aceitação das componentes recalcadas da nacionalidade coloca-se de modo indissolúvel o problema do outro como expressão literária.

Partimos da concepção de que o modernismo promove uma discussão acentuada sobre a alteridade oriunda do forte engajamento do movimento no tocante a consciência do país. Contudo, atento às idiossincrasias estéticas e ideológicas que atravessam a formação dessa escola literária no Brasil, realizemos uma análise sobre a construção desse outro pelo poeta em diferentes fases do Modernismo, mais especificamente, a "fase heróica” de 22 e a geração de 30, 
nos textos Dois poemas acreanos, de Mário de Andrade e O operário no mar, do poeta Carlos Drummond de Andrade, a fim de percebemos os pontos de encontros e desencontros na poética desses autores no que toca o assunto sobre o outro.

\section{O MODERNISMO DE 22 ENCONTRA O DE 30: ATRITOS E CONVERGÊNCIAS NA POÉTICA DE MÁRIO E DRUMMOND}

Não pretendemos realizar um apanhado sobre os antecedentes que impulsionaram o surgimento do movimento modernista até a sua efetiva concretização personificada no acontecimento da Semana de Arte Moderna de 22, nem as diversas características que emolduram o movimento. Queremos aqui explanar, brevemente, os atritos, as conquistas, as dependências e a superação entre as fases de 22 e 30 com o propósito de delinear o engajamento de Mário e Drummond no reflexo de suas poéticas.

Sendo assim, é necessário enfatizar que a transição desse processo não é marcada por extremas rupturas, trata-se, antes de tudo, de uma mudança de ênfase, o que antes era tratado como coadjuvante ganha o protagonismo. O que temos como pano de fundo que abarca a totalidade do movimento é uma necessidade e clamor de conhecimento e interpretação da realidade nacional, que desconstruísse toda uma visão de país subjugada à produção cultural anterior. Segue-se o mesmo desejo, mudam-se as armas de conquista: enquanto a expressiva experimentação estética marca os primeiros anos do modernismo, a geração de 30 floresce sob o peso das lutas ideológicas, da consciência de classes, da opressão do atraso do país. João Luiz Lafetá realiza uma comparação da fase heroica e da que segue a Revolução, dividindo-as basicamente: na primeira, um projeto estético, que discute principalmente a linguagem e, na segunda, uma ênfase sobre o projeto ideológico, que debate "a função da literatura, o papel do escritor, as ligações da ideologia com a arte” (1974, p. 17).

Mas as permanências também são características dessa transição de fases e manifestase, principalmente, na poesia, gênero que mais radicalmente se modificou no Modernismo. Mário, Oswald e Bandeira romperam profundamente com o academicismo na lírica. O verso livre, o tom coloquial, o prosaico, a ironia foram, mais do que conquistas, revoluções tão grandes que são impossíveis aos poetas da década de 30 ignorá-las. Drummond, Jorge Lima, entre outros são herdeiros diretos desse roteiro, por mais que busquem conquistas temáticas distintas das antes preconizadas. 
É sob o embalo desses descompassos e continuidades que colocamos em foco as poéticas de Mário e Drummond. As correspondências entre eles mantidas e a recorrência de assuntos e temas na poesia de ambos abrem espaço para o reconhecimento de seus respectivos posicionamentos em grande parte derivados dos conflitos que permeiam suas respectivas fases do modernismo brasileiro. Porém, pensar nas poéticas de Mário e Drummond requer uma abolição das superficialidades e imediatismos que distinguem as características de cada geração. Citamos anteriormente a ênfase dada pela geração de 22 ao plano estético em contraponto ao peso ideológico conferido pelos autores de 30, por mais legitimidade que essa afirmação adquira ao longo da historiografia literária guiar uma análise comparativa na base desse dualismo limita e apaga todo o peso das contradições, em maior ou menor grau, que permeiam as obras desses autores.

Isso porque a linguagem contém em si traços ideológicos e a própria ideologia emerge por meio de uma construção estética. Arte e engajamento devem ser vistos sob um prisma dialético; onde há somente o conteúdo trata-se de panfletagem, a forma por si é hermetismo, o "conteúdo da obra de arte há de converter-se em forma para que sua verdadeira materialidade de conteúdo chegue a ter efeito artístico". (BASTOS, ONLINE, 2016). Esta preocupação atinge a lírica desses dois poetas, mas distingue-se nos modos de solução encontrados.

Em seus estudos sobre Mário, Lafetá discute que o escritor se torna tão interessante e importante justamente por causa das contradições que apresenta, reconhecidas por ele próprio. A tensão entre as necessidades sociais e sua escrita, ou como diz "o problema da contradição entre o intelectual que sou e o comunista que sou" apesar de angustiar o poeta são encaradas com lucidez. O crítico ainda aponta a dificuldade de Mário encontrar uma saída que superasse "a contradição do pequeno burguês paulista e a consciência do escritor culto, que já ultrapassara esse sentido político, exclusivista, proprietário, de pátria” (LAFETÁ, 1974, p. 45). Apesar de sempre ter feito obra política, Mário de Andrade permaneceu coerentemente o que sempre foi um escritor, e se a condição de pequeno burguês o impelia de dar um passo social, a sua consciência estética torna-se uma aliada na tentativa de apaziguar essa deficiência.

Mário, em O Movimento Modernista, relata que toda sua obra foi pautada por um antiindividualismo e conclui que toda ela não é mais que "um hiper-individualismo implacável", pensamento este tão paradoxal, mas que abre portas para entender sua arte. É na forma poética que Mário promove seu engajamento, ou melhor, sua tomada de posição dá-se pela forma, espécie de refúgio o qual pode expurgar a culpa por essas lacunas sociais e ao mesmo tempo reconciliar as diferenças. $\mathrm{O}$ apelo da linguagem não deixa de ser acima de tudo um processo de 
realização individual do poeta, mas que se traveste numa realização coletiva casada com o desejo de nacionalidade de 22.

Mário tem consciência das limitações de sua posição e da própria geração, ele próprio confessa o aristocratismo do movimento, posição que dificilmente promoveria o mesmo ânimo nos outros por um instinto de nacionalidade do que causava neste pequeno grupo. $\mathrm{O}$ modo mais eficiente de sanar esse conflito dá-se pelo apelo sensível do reconhecimento de si, do outro e da nação por um filtro cultural de fácil identificação.

Observemos seu livro Clã do Jabuti ${ }^{2}$ (1927), nas palavras de João Luiz Lafetá:

Espécie de repertório do Brasil inteiro, em que a dança do 'Carnaval Carioca' se mistura à meditação do 'Noturno de Belo Horizonte', o 'Côco do Major' Venâncio da Silva convive com a 'Moda da Cadeira de Porto Alegre' e com a cama paulista de Gonçalo Pires, ou, por fim, a escrivaninha da Rua Lopes Chaves descobre em assombro o acreano pálido magro de cabelos escorrendo nos olhos. (LAFETÁ, 1974, p. 141).

Nesse livro Mário reflete na sua poesia todo o extenso repertório de pesquisas folclóricas, compondo um painel extenso de toda a cultura brasileira. Evoca-se uma renovação do que é ser brasileiro, de suas particularidades, por meio de um registro moderno e apurado dos mitos, das lendas, das cantigas, do que há de mais primário e substancial provindo dos matizes africanos, indígenas e sertanejos. O trabalho estético de Mário, emoldurado por uma constante musicalidade típica nos versos e uma linguagem coloquial, serve a um propósito explicitamente nacionalista: a construção de uma identidade brasileira pluralística, enraizada na tradição popular. Os homens do povo, as diferentes regiões com seus hábitos distintos são constantemente enfocados na série de poemas que constitui o livro (BARATA, PEREIRA, 2007).

Mário promove uma dinâmica: acentua as particularidades que compõem o país, contudo as engloba numa totalidade - o clã , o sentido de identidade brasileira ocorre por meio de conciliações, por mais distintas que possam ser. Essa "brasilidade" do poeta é conferida por uma inclusão total e absoluta, o nacionalismo marioandradino não se pauta em exclusões para conferir uma entidade particular, todo o processo é vivo, inclusivo e dialético. Por essa razão, “o outro, como conjunto fragmentado em individualidade, mas unidos por características comuns, é de maneira geral a temática central do Clã do Jabuti" (PAULA, 2006, p. 5).

Entretanto, é importante ressaltar que essa vontade de estar com o outro não parte apenas de um desejo inconsciente do poeta, ela atende a uma necessidade maior de engajar-se, de

${ }^{2}$ Dois poemas acreanos e Operário no mar, poemas aqui analisados, se encontram, respectivamente, nos livros Clã do Jabuti e Sentimento do Mundo. 
fazer valer o projeto ideológico do movimento. Além de que esse outro se transmuta na própria forma que lhe é de origem, cujo efeito respalda mais no construto de um mito cultural do que o outro como pessoa inteira. Quando citamos, previamente, o hiper-individualismo de Mário e suas escolhas acessíveis está, pois, na maneira como ele ensaia resolver esses conflitos ao redor de sua poética: o espírito da época, o otimismo efusivo, essa consciência ainda primária do subdesenvolvimento não abre espaço aqui para a problematização, para angústias ou mártires. Abraçam-se as deficiências, totalizam-se as diferenças, Mário parece escolher, por fim, o caminho da conciliação.

Ao passo que Drummond, em Sentimento do Mundo (1940), inaugura uma fase dialética em sua obra, a perspectiva brasileira não é mais pitoresca, está entranhada. O poeta parte de uma poesia aguerrida a uma participação política e de forte preocupação dos problemas de seu tempo, contudo esse engajamento não torna sua poesia limitada quanto à forma estética, pelo contrário, a participação vem em chave de lirismo. No estudo Inquietudes na poesia de Drummond, Antonio Candido (1965) ressalta as contradições da matéria poética do autor, o eu e o mundo são assuntos de sua poesia, o desejo de compreensão das problemáticas sociais entra em choque com a invasão de elementos subjetivos e biográficos que refletem em seus poemas. A inquietude que toca o poeta vem acompanhada de remorso, da sensação de culpa que o impulsiona a vontade de escapar desse eu e conhecer o outro, de situar-se no mundo, "a consciência crispada, revelando constrangimento da personalidade, leva o poeta a investigar a máquina retorcida da alma; mas também a considerar a sua relação com o outro, no amor, na família, na sociedade." (CANDIDO, 1965, p. 75).

Na poética de Drummond, o subjetivo invade o social, e o social tem origem no construto da subjetividade, das vivências do poeta. A dialética que atravessa sua poesia está contida no próprio titulo do livro: "Sentimento" intui a uma expressão particular, "mundo" carrega uma semântica coletiva, a reprodução do mundo é feita na particularidade do poeta. $\mathrm{O}$ sentimento de solidão e o isolamento do intelectual são os pontos de partida para o conhecimento de um mundo que se encontra alienado, nas palavras do poeta "o mundo caduco", "o triste mundo fascista". A matéria lírica é de uma agudez da consciência do poeta, consciência que vem em forma de raiva da própria desumanidade, sua dor nunca volta a si mesmo, não é de autopiedade; pelo contrário, a dor do poeta tem uma construção histórica provinda da consciência da luta de classes, da reificação social perante o capitalismo. Seu canto é a dor do intelectual em relação ao privilégio de classe, o qual sente culpa por dela fazer parte. Tal consciência social permite um sentido autêntico de militância através da poesia, uma 
possibilidade de "resgatar a consciência do estado de emparedamento e da existência da situação de pavor" (CANDIDO, 1965, p. 73).

Ainda no texto Inquietudes, Antonio Candido traz uma pergunta que aparece periodicamente na obra de Drummond, mas também que problematiza a questão de uma representação da alteridade e que aqui reestruturamos: se o alvo da poesia é o próprio poeta pode esta "impura matéria" torna-se objeto de interesse para o outro? Até que ponto se pode pensar em alteridade na poética drummondiana tão centrada nas angústias desse poeta? Na carência de respostas concretas, usamos as suposições e todas elas passam pelo campo da consciência. Drummond tem consciência dessa distância do outro, sabe que nunca haverá uma relação de reciprocidade, a distância de classes transforma-se numa distância física pela posição aparteadora do poeta, mas, diferente de Mário, ele não usa seu lirismo como meio de reconciliação com o outro, até mesmo porque ele não quer, o que de fato Drummond almeja é mimetizar sua dor como instrumento de conhecimento.

A posição de intelectual permite ao autor "sentir esse mundo", não de um modo banal, mas sim em pensar acerca do mundo, a provocar um entendimento. Drummond aborda a questão do outro como problema de todos, o despertar da luta de classes confere não a reconciliação, mas a identificação para com o outro, e nesse aspecto a obra abre-se para uma universalidade.

\section{A ALTERIDADE COMO TOMADA DE CONSCIÊNCIA}

Nos poemas Dois poemas acreanos e $O$ operário no mar, Mário e Drummond convergem suas poéticas ao tratar da questão da alteridade. Ambos os poemas partem de uma situação semelhante: a do poeta que assumindo sua distância e seu papel, a de intelectual, almeja falar sobre o outro, estar com o outro, solidarizar-se e tentar compreendê-lo. Independente de ser um seringueiro ou um operário, o outro é a materialização da distância que o poeta atesta: o homem simples, inculto, indiferente à presença do poeta. Rufinoni (2013), no seu artigo comparativo Mário e Drummond: nacionalismo, alteridade e arte, anuncia essa aproximação dos dois poemas, unidos pelo confronto da alteridade, partindo do desejo do poeta de aproximar-se desse outro, da tomada de consciência de sua ignorância perante essa realidade e a certidão dessa indiferença.

Se a difícil questão da alteridade é a problemática que une os poemas, o ponto de entrecruzamento deles se desenlaça na construção de um reflexo lírico que expõe os diferentes posicionamentos de Mário e Drummond perante o pensar do fazer poético, das relações que 
estabelecem entre a lírica e o social e da projeção dessa poesia frente a períodos distintos de participação. Atentamos, a seguir, a uma leitura dos poemas.

Dois poemas acreanos nasce de uma dicotomia, o eu e o outro, a caminho de uma unificação, o nós, e a divisão do poema é a prova disso. O texto divide-se em duas partes: na primeira intitulada "Descobrimento", o poeta "abancado à escrivaninha em São Paulo" dá-se conta da existência do outro personificado no seringueiro do Acre. Essa parte estrutura-se em duas estrofes cada qual com cinco versos e fecha-se num verso monóstico, embalada pela tríade eu, ele, nós.

Na primeira estrofe o olhar está no poeta, na segunda o poeta volta-se ao seringueiro e por último há uma tentativa de igualar os dois. É a partir do achado desse outro, que lembra muito um processo epifânico "Meu Deus!", que o poema se constrói numa interface dualística marcada por descrições concretas as quais reforçam essa distância do eu e do outro: São Paulo versus Acre, observador versus observado, escritor versus seringueiro. A escuridão que atravessa a primeira fase do poema - com forte marcação da noite - evidencia essa distância. A noite é a hora do escritor, de todo seu processo de criação em contraste com o horário do trabalho do seringueiro, o dia. Quando um está para dormir o outro está para acordar. Logo, a possibilidade desse encontro se não inexistente, ao menos é dificílima.

A caracterização desse seringueiro "um homem pálido magro de cabelos escorrendo nos olhos" (v.8), muito específica, opõe-se com a inexatidão que deveria ter essa imagem, uma vez que o poema é permeado pelo filtro do sentir, do lembrar "Não vê quem me lembrei que lá do norte, meu Deus! muito longe de mim" (v.6) e não do realmente visto. Perpassa um tom de efabulação no construto desse outro, tudo se encontra no plano das sensações - forte semântica tátil - e dos sentimentos. A existência do outro para o poeta sempre é mediada "sentir pelo que me contam", passando desde o campo das impressões até pelo "despotismo dos livros". Mário realiza um olhar macroscópico não sobre o outro, mas sobre o que seria o outro.

A primeira parte do poema termina no encontro do eu e desse homem por uma característica que os liga: o ser brasileiro. Mário tenta atenuar essas distâncias evocando um sentimento que os unifica, o nacionalismo "Esse homem é brasileiro que nem eu..." (v.11), que entrelaça poeta e seringueiro, num verso que demonstra mais uma reflexão do que um atestado de confirmação.

A segunda parte intitulada "Acalanto do seringueiro", é marcada por uma construção melodiosa. Mário traz à sua lírica uma forma popular, o acalanto, canção musical usada para 
embalar crianças e bebês, ou seja, as cantigas de ninar. Acalanto ainda possui uma ligação semântica de calor, quentura e perpassa uma ideia de aquecer, confortar, aliviar. Tal tom que envolve a segunda parte do poema provém do reconhecimento de incapacidade do próprio poeta em representar/cantar sobre esse outro. "Que dificuldade enorme!/ Quero cantar e não posso/ Quero sentir e não sinto" (v.18-20) e de que sua poesia é indiferente a "Essas coisas para você/ Devem ser indiferentes/ Duma indiferença enorme" (v. 97-99). Ao passo que o poeta tenta recompensar tal incapacidade mistificando o desconhecimento e as incertezas, fetichizando o homem e o natural "a escureza da floresta", "o mato-virgem do Acre”, "a aspereza desse chão".

A forma poética - o acalanto - entra como meio estético de consolar e ao mesmo tempo lisonjear esse outro, além de conferir uma tentativa de identificação mais imediata devido ao caráter popular da composição. Já na temática, o autor traz uma de suas maiores preocupações, o nacionalismo como matéria a unir poeta e intelectual. Os dois se igualam quando o poeta os projeta a um quadro muito maior, como filhos de uma nação que partilham as mesmas dores da exploração de tempos remotos. Marca-se assim a virada de tom no poema, trazendo a condição de nós na quarta estrofe:

Mas porém é brasileiro,

Brasileiro que nem eu...

Fomos nós dois que botamos

Pra fora Pedro II...

Somos nós dois que devemos

Até os olhos da cara

Pra esses banqueiros de Londres...

Trabalhar nós trabalhamos

Porém pra comprar as pérolas

Do pescoçinho da moça

Do deputado Fulano.

Companheiro, dorme!

Porém nunca nos olhamos

Nem ouvimos e nem nunca

Nos ouviremos jamais...

Não sabemos nada um do outro,

Não nos veremos jamais! 
Nessa consciência da distância do outro e da angústia provocada por esse conflito o nós dissolve-se e o poema continua apartado pela divisão do eu e do outro. Contudo, Mário reconcilia essa insuficiência de modo complacente, em um abraço, um “amor-de-amigo". Por outro lado, é importante ressaltar que essa tentativa, mesmo que física, de igualar os brasileiros expõe uma ironia dialética, pois o próprio "tom paternalista" do poema já evoca uma relação de desigualdade. A construção estética (o acalanto) aproxima, mas também remarca uma fratura, uma assimetria entre planos, uma desigualdade.

Se ao longo do poema a imagem do seringueiro se repete, o poeta encerra seu acalanto na figura do brasileiro, sinalizando que o encontro desses dar-se-á num horizonte de projeção da identidade nacional, lugar em que as diferenças se ressaltam ao mesmo tempo em que se anulam no ser brasileiro. A alteridade, em Mário, passa por uma construção cultural.

Enquanto que em Operário no mar, o olhar do poeta perante o outro é microscópico (a rua) e horizontal (campo, mar). A construção do texto, o poema em prosa ${ }^{3}$, evidencia a eventualidade, a natureza acidental da ação que converge com o aspecto ordinário do operário "Esse é um homem comum, apenas mais escuro que os outros..." (1.3). A casualidade representada por Drummond alarga e universaliza o espaço de atuação do poema, o operário que o poeta vê pode ser qualquer um em qualquer lugar. Diferente de Dois poemas acreanos, cujos espaços físicos são demarcados, a distância aqui não é contextualizada. Em Operário no mar, a única divisão visivelmente demarcada é a da diferença de classes. Abre-se espaço, para outra chave de consciência no poema: Drummond trabalha o outro sob o contexto de reificação do mundo.

Sua dor e solidariedade ao outro não está pela distância que os separa ou no desejo de aproximação, mas pelo alheamento, a condição opressora a qual o operário está inserido e não reconhece "O operário não lhe sobra tempo de perceber que eles levam e trazem mensagens, que contam da Rússia, do Araguaia, dos Estados Unidos. Não ouve na Câmara dos Deputados, o líder dos oposicionistas vociferando" (1.7).

Drummond trabalha a figura do operário aludindo-o a Cristo "Agora está caminhando no mar. Eu pensava que isso fosse privilégio de alguns santos e navios" (1.15), contudo o autor subverte as expectativas e a idealização nunca se realiza por completo "Mas não há nenhuma santidade no operário, e não vejo rodas nem hélices no seu corpo, aparentemente banal.” (1.16)

\footnotetext{
${ }^{3}$ Segundo Clive Scott, "uma das qualidades fundamentais do gênero está na sua capacidade de preservar a natureza acidental dos eventos, levando com frequência a uma 'expressão sem controle'. Escrita descontrolada, acionada pelo acaso, mas ao mesmo tempo com reiterado sentido de poema e unidade estética.” (apud PAIXÃO, 2013 p.12)
} 
Não existe espaço para recorrer ao misticismo de Mário, a consciência catastrófica do atraso, de que fala Antonio Candido, não permite ao poeta elencar ares de cristandade ao operário nem permite ao poeta traçar laços fraternais “Ele sabe que não é, nunca foi meu irmão, que não nos entenderemos nunca. E me despreza... Ou talvez seja eu próprio que me despreze a seus olhos" (1. 12).

A indagação final "quem sabe um dia o compreenderei” apesar de abrir uma promessa de comunhão no horizonte da luta social, não prescinde do abismo da distância entre eu e o outro "enunciado pela imagem sublime do operário que caminha sobre as águas da história, simbolicamente partidas para sua passagem.” (RUFINONI, 2014, p. 257) Porém, afora o reconhecimento que o poeta tem da indiferença perante o outro e das posições que ocupam , a construção estética do texto permite igualar esses dois: o olhar de Drummond nunca aponta uma assimetria, mas uma igualdade de plano. O mar e o campo abrem-se como uma ligação natural, espécie de identificação comum a todos os homens, um identitário universal, independente do domínio capitalista "A fábrica ficou lá atrás. Adiante é só o campo, com algumas árvores, o grande anúncio de gasolina americana e os fios, os fios, os fios" (1.4-5).

Nesse sentido é que o poema de Drummond expande sua atuação, projetando o texto a uma universalidade. O que sobra é uma tentativa de compreensão do outro, se o que permeia o poema é um tom de profunda melancolia, a consciência em relação à figura do outro abre espaço para a esperança: no mar, no campo, na resposta de um sorriso.

\section{CONSIDERAÇÕES FINAIS}

A tomada de consciência da limitação do lugar de fala do poeta emana dois modos de conceber o outro: a distância que se elimina perante a união da identidade nacional e a distância que se alarga no aparente irremediável conflito de classes.

A alteridade manifesta-se na poética de Mário e Drummond conivente com suas respectivas posições de engajamento dentro do movimento modernista: o outro marioandradino é o resultado das contradições que permeiam sua obra, as quais ele não conseguiu solucionar. Eleva-se o outro a alcunha mística como meio de suprimir as deficiências do poeta na condição de pequeno burguês e, ainda assim, atender ao desejo de busca de uma identidade nacional popular da "fase heroica". Se essa atitude demonstra uma complacência, também traz resquícios, na forma poética, de uma tradição colonialista/ paternalista por parte do poeta, sendo o outro 
ainda é visto por um prisma assimétrico, que deflagra uma desigualdade. Contrário a Mário está Drummond, oriundo da geração de 30 e da consciência catastrófica do atraso, transforma suas inquietudes em poesia como meio de conhecimento perante o mundo reificado. Transpõe as barreiras nacionais universalizando o outro por meio de uma questão bem maior: a divisão de classes, que aparta os homens indissoluvelmente.

\section{REFERÊNCIAS}

ANDRADE, Carlos Drummond de. Sentimento do mundo. 4ed. Rio de Janeiro: Record, 2004.

ANDRADE, Mário de. O Clã do Jabuti (1927). Projeto Livro Livre. São Paulo, 2016.

Horizonte: Itatiaia, 2012.

.O movimento modernista. In: Aspectos da Literatura Brasileira. Belo

BARATA, Mariana Moreira Fernandes e PEREIRA, Maria Luiza Scher. Manifesto Antropófago e Clan do Jabutí: o discurso identitário brasileiro no modernismo. Revista Gatilho, Ano III, Volume 5, Julho 2007.

BASTOS, Hermenegildo. Arte e vida cotidiana: a catarse como caminho da desfetichização. Disponível em: https://herramienta.com.ar/articulo.php?id=2237

Formação e Representação. Cerrados: Revista do Programa de PósGraduação em literatura, n.21, ano 15, 2006, p.91-112

BOSI, Alfredo. História Concisa da Literatura Brasileira. 43 ed.- São Paulo: Cultrix, 2006.

CANDIDO, Antonio. Inquietudes na poesia de Drummond. In: Antonio Candido: vários escritos.

- Formação da literatura brasileira: momentos decisivos. 6. Ed. Belo Horizonte, Editora Itatiaia Ltda, 2000.

. Literatura e cultura de 1900 a 1945. In: Literatura e Sociedade. 9a edição Ouro sobre azul: Rio de Janeiro, 2006.

CARLI, Ranieri. Lukács, Literatura e o Imperativo da Catarse Realista. I Colóquio Internacional $O$ realismo e sua atualidade: estética, ontologia e história, 2014.

LAFETÁ, João Luiz. 1930: a crítica e o modernismo. São Paulo, Duas Cidades, 1974.

LARROCA, Arianne e FERNANDES, Pedro Henrique. Resenha A conquista da América: A questão do outro. Epígrafe. São Paulo, 2013.

GUSMÃO, Neusa Maria Mendes. Linguagem, Cultura e alteridade: imagens do outro. Cadernos de Pesquisa, n. 107, 1995. 
MACHADO, Márcia Alves de Carvalho: A alteridade intrínseca na teoria marxista: um estudo a partir da obra "O capital". Disponível https://olimpiadadefilosofiasp.files.wordpress.com/2012/03/alteridade_intransica_teoria_marxista_estudo_partir_obra_capital.pdf Acesso em fevereiro de 2017.

PAULA, Adna Candido. A dimensão de alteridade na poesia de Mário de Andrade: inclusão na diversidade. Conexão Letras volume, n. 2, 2006.

PACHECO, Joice Oliveira. Identidade cultural e alteridade: problematizações necessárias. Spartacus- Revista Eletrônica dos Discentes de História. UNISC, 2007.

PAIXÃO, Fernando. Poema em prosa: problemática (in)definição. Revista Brasileira. Fase VIII. Ano 2. N. 75. Abr.mai.jun/2013.

RUFINONI, Simone Rosinetti: Mário e Drummond: nacionalismo, alteridade e arte. Estud. av. vol. 28 n.80. São Paulo, 2014.

SIDEKUN, Antonio. Cultura e Alteridade. In: Cultura e Alteridade: Confluências. Ijuí, Rio Grande do Sul, Brasil, 2006.

SPERBER, Suzi frankl. A identidade literária brasileira: uma petição de princípios? Remate de Males, Campinas (14): 153,159, 1994.

TODOROV, Tzvetan. A conquista da América: A questão do outro. $2^{\mathrm{a}}$ ed- São Paulo, Ed. Martins Fontes. Disponível em: http://www.portalconservador.com/livros/Tzvetan-Todorov-AConquista-da-America.pdf. Acesso em fevereiro de 2017.

ZANELLA, Andrea Vieira. Sujeito e alteridade: reflexões a partir da psicologia históricocultural. Psicologia e Sociedade, 17 (2): 99-104; 2005.

Recebido em: $29 / 10 / 2018$

Aprovado em: 11/11/2018

Publicado em: 10/12/2018 